University of Nebraska - Lincoln

DigitalCommons@University of Nebraska - Lincoln

The Nebraska Educator: A Student-Led Journal Department of Teaching, Learning and Teacher

Education

Spring 10-21-2020

Seeing Formative Assessments from a Broad Perspective

Consuelo Marisol Gallardo

University of Nebraska-Lincoln, cgallardochangotas2@huskers.unl.edu

Follow this and additional works at: https://digitalcommons.unl.edu/nebeducator

Part of the Bilingual, Multilingual, and Multicultural Education Commons, and the Teacher Education and Professional Development Commons

Gallardo, Consuelo Marisol, "Seeing Formative Assessments from a Broad Perspective" (2020). The Nebraska Educator: A Student-Led Journal. 47.

https://digitalcommons.unl.edu/nebeducator/47

This Article is brought to you for free and open access by the Department of Teaching, Learning and Teacher Education at DigitalCommons@University of Nebraska - Lincoln. It has been accepted for inclusion in The Nebraska Educator: A Student-Led Journal by an authorized administrator of DigitalCommons@University of Nebraska - Lincoln. 


\title{
Seeing Formative Assessments from a Broad Perspective
}

\author{
Consuelo M. Gallardo \\ Department of Teaching, Learning, and Teacher Education \\ University of Nebraska-Lincoln
}

\begin{abstract}
Despite the fact that many experts in the assessment field have advocated for the use of formative assessments, little attention has been paid to their thorough elaboration and application in Ecuadorian English as Foreign Language (EFL) classrooms. Some teachers have overlooked the validity of formative assessment as tools to inform instruction and language learning growth, so its application has generated a big debate. Therefore, this paper presents a literature review of perceptions and experiences of diverse scholars and practitioners who have analyzed the validity of formative assessments and conducted studies in EFL classrooms. It starts by providing information related to the characteristics and purposes of formative assessments. It also describes their application and impact on teaching and learning. It highlights how formative assessments can invite students to take learning ownership and provide immediate feedback to improve language development. Subsequently, it shows the advantages and challenges of formative assessments, which include peer reviews, peer assessments, self-assessments, and portfolios. Additionally, it points out the effects of formative assessments to check students' language proficiency growth and teacher awareness. Finally, it discusses a summary of encouraging and challenging literature review findings, future research questions, and a call for action. This literature review invites EFL teachers to see formative assessments from a broad perspective increase their awareness and reflect on their further applicability.

Keywords: teaching, formative assessment, feedback, English language skills

doi: 10.32873/unl.dc.ne010
\end{abstract}


Over the years, teachers have been required to conduct standardized tests for English language learners to assess their English knowledge, as well as their receptive and productive skills. This summative assessment practice has been conducted in English-speaking countries and in countries where English is considered as a second or foreign language. Although summative assessments have been considered as reliable tools to gather data that informs instruction and helps learners improve their English proficiency, it is not necessarily the case in some Ecuadorian EFL classrooms.

To illustrate, as an English teacher I have heard high school students complaining about summative assessments and stating that they have not been very useful to advance in their English level. Some students have even argued that these assessments do not have consequential validity since they do not see them as learning experiences. Besides, they usually emphasized that summative assessments do not allowed them to receive effective feedback in order to improve their English proficiency level. As Pat-El, Tillema, and Segers (2013) mentioned, it is difficult for students to obtain real evidence of their learning progress and reach high standards if they only receive a quick and general review based on their final tests' results. It leads teachers to move on without actually reinforcing students' language skills and make some learning improvements.

In the Ecuadorian case, while working as a teacher, I have seen that not only students expressed dissatisfaction with their lack of English proficiency, but also educational authorities had concerns about students' low English level. They have argued that although in 2011, the Ecuadorian national guidelines from the Ministry of Education established that students have to take five English class periods per week throughout six academic years, students do not have an intermediate English level by the time they graduate from high school. Consequently, they 
complain that students have not acquired the necessary knowledge and skills to reach the mandatory Intermediate English level (B1) based on the Common European framework of reference for languages which have been adapted from the Council of Europe (2011). As a result, this reality has forced higher education authorities to continue hiring English teachers so that college students can take more courses for three or four years until they reach the intermediate English level.

Besides, Serrano, Vizcaíno, Cazco, and Kuhlman (2015) indicated that many Ecuadorian English teachers do not have "the methodologies to teach English effectively in the schools" (p. 109). As such, if research shows that English instruction has been ineffective and not good enough to help EFL students, it is crucial to start considering not only useful teaching practices but also assessment tools that allow teachers and students to obtain better English language achievements.

As Black and William (1998), Bloom (1969), Cauley and McMillan (2010), as well as Hattie and Timperley (2007) highlight, formative assessments are tools that assist teachers to inform their instruction and provide the necessary support to help students improve their English language knowledge and skills. Besides, they argue that formative assessments report valid information about students' language progress and allow teachers to provide constant and immediate feedback since these assessments reveal specific learning strengths and weaknesses. Hence, this supportive assessment practice allows students to receive scaffolding instruction to advance them in their learning and be better prepared to get high achievement standards.

Despite the fact that many experts in the assessment field have advocated for the use of formative assessments in EFL classrooms, little attention has been paid to their thorough elaboration and application in many countries, including Ecuador. To exemplify, while working 
at the public and private sector, I had observed that some colleagues do not consider formative assessments as practical tools since not only its elaboration, but its application demands too much work, especially when having forty or fifty students per class. Thus, formative assessments have been seen as tools that have unclear grading purposes, demand a lot of planning and grading, and reduce class time to complete other grade-level contents.

Consequently, there is a need to explore more theories and research studies like the one from Lee and Coniam (2013) about the effective use of formative assessments in EFL classrooms to advocate for their effective implementation in public high schools. Once teachers realize that formative assessments can help them gather real evidence about the students' language progress and inform their instructional practices, they would start relying on them. What is more, they would be more likely to start applying them in their classrooms when assessing students.

To accomplish the overarching goal of inviting EFL teachers to see formative assessments from a broad perspective, this research-based paper presents perceptions and experiences of diverse scholars and practitioners. It starts describing information about formative assessments. It also highlights the impact of formative assessment in EFL classrooms and its implications and presents information about the relevance of teacher training before implementing them. Finally, it closes with a call for action.

\section{Literature Review}

\section{Dynamic Assessment Characteristics}

Assessments are considered as important teaching and learning tools since they influence both teachers' and students' lives. Thus, according to Richards (2015), their application has been 
essential not only to inform teacher instruction but to monitor student progress while identifying strengths and weaknesses to providing effective feedback.

Varying Purposes of Formative Assessment. When describing formative assessments or also known as assessments for learning, Brown and Abeywickrama (2018) state that "they have as their primary focus the ongoing development of the learner's language" (p. 8). It allows teachers to constantly assess student progress that occurs during the process of an instructional cycle. Similarly, these assessments gather relevant data of student learning to provide support to modify instructional practices. Gottlieb (2016) also affirms that formative assessments allow teachers to receive permanent and descriptive feedback on students' knowledge and skills for making improvements to help them advance in their learning. Likewise, Gordon and Rajagopalan (2016), Heritage (2010), Moss and Brookhart (2009), and Popham (2008) have mentioned that the main purpose of formative assessments is to offer relevant information (feedback) for teachers and students. On one hand, teachers use formative assessments to get real evidence of student learning, go under a reflective process, and make decisions to modify their instruction to facilitate student learning. On the other hand, students receive specific evidence of their own learning progress, understand and identify their strengths and weaknesses, and take actions to keep improving. Despite the fact that many authors have provided varying functions of formative assessment as tools that offer information about the teaching practice and learning growth, Figure 1.1 attempts to summarize its most common purpose. 


\section{Figure 1.1}

Formative Assessment Purpose

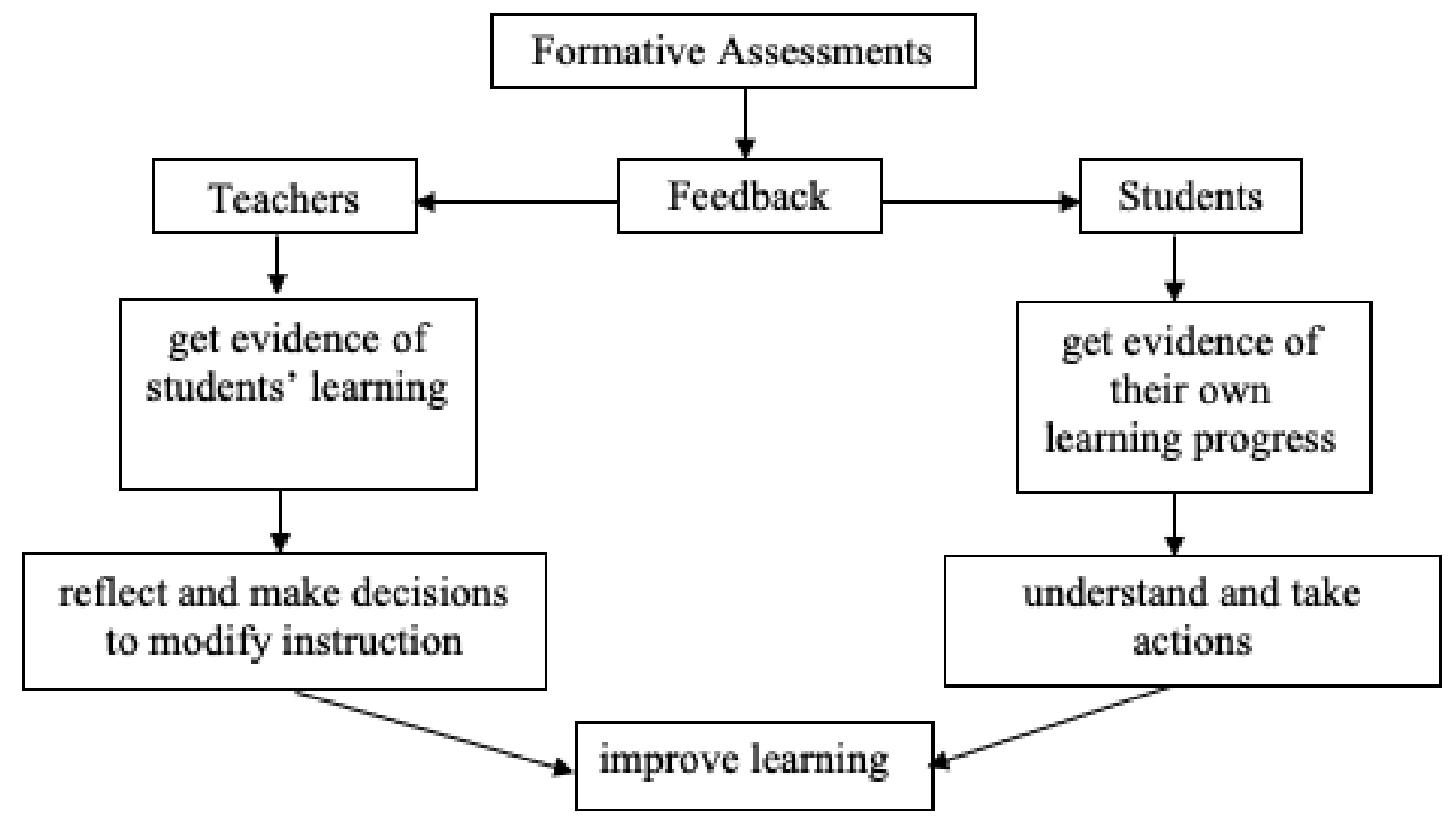

As assessment practices are fundamental for identifying student performance, Gottlieb (2016) emphasizes that it is vital to have specific purposes when assessing English language students in order to avoid misinterpretation of their results. To exemplify, if an assessment purpose is to determine whether or not students need extra language support, teachers can apply language and literacy surveys. When the purpose is to enhance English language teaching and learning, teachers can implement instructional assessments, peer assessments, and selfassessments. However, if its purpose is to monitor students' language progress over time, teachers can use portfolios and journals. Thus, the following information highpoints research exemplars to show how formative assessments can be useful as long as there is a clear purpose for their implementation. 
Essential Aspects about Formative Assessments. When conducting formative assessments, it is relevant that teachers have a clear idea of what they want to assess, and how, when, and why they want to do it. This leads to formulate clear purposes and establish welldefined descriptors so that students can show their learning while teachers take time to unveil their strengths and weaknesses related to content and language skills.

To exemplify. Chappuis and Stiggins (2002) mention that formative assessments are seen as effective tools by students when they have a clear idea of what it is the expected overarching learning goal that they need to accomplish, what their current and future learning achievement looks like, and what necessary actions they should take in order to advance in their learning. To provide more information about it, three essential aspects of formative assessment practices are depicted in Figure 1.2. 


\section{Figure 1.2}

Essential Aspects of Formative Assessment Practices

\begin{tabular}{|l|l|}
\hline Formative assessment practices... & Students need to... \\
\hline offer students a clear final learning goal they need to & know the final learning goal \\
accomplish and explains why they need to do that & \\
\hline provide students specific information of their current & understand the current learning \\
learning goal & \\
\hline motivate students to take actions to improve their & meet the final learning goal \\
knowledge and skills in order to reach the final & \\
learning goal. & \\
\hline
\end{tabular}

This information clearly explains that formative assessments provide concrete and useful data for both, students and teachers. While students use the provided data to monitor their own learning growth, teachers can use it to differentiate their instruction in order to meet students' needs. As Gottlieb (2016) highlights, students and teachers play an important role when assessing learning. Therefore, there is no reason for teachers to feel overwhelmed and think that they have all the responsibility to conduct multiple formative assessment practices by themselves. 


\section{Incorporating Formative Assessment in EFL Classrooms}

In some EFL classrooms, students have been part of traditional assessment practices for many years since teachers have relied on standardized test to check students' English knowledge. However, as Colley (2008) highlights, traditional assessment practices that only takes into account standardized tests to evaluate students do not really show what students know. Besides, they do not invite students to take ownership of their own learning, and it leads students to have constant struggles to see clear English learning improvements. Therefore, when students do not have the opportunity to take part in their language assessment process, so they just rely on teachers to receive feedback and guidance to improve their language knowledge and skills.

Nevertheless, not only Bloom (1984) but also Leahy, Lyon, Thompson and Wiliam (2005) mention that teachers can use formative assessments as tools to invite students to take more responsibility for their own development throughout the learning process, and start relying more on their classmates' support.

Promoting Ownership for Learning. There have been several researchers who have conducted studies in EFL classrooms to see if formative assessments are reliable methods that can make a positive impact and give students the opportunity to take control of their own learning. For instance, Jing Jing (2017) conducted a case study in Hong Kong and included one teacher and eight students in order to examine whether or not the use of formative assessment practices in an EFL classroom can facilitate student self-regulation. Thus, the use of lesson observations, video recording, teacher and student interviews, and surveys allowed the researcher to find out that formative assessment practices really support student self-regulation. Similarly, this research findings showed that these assessments help students clarify their understanding, receive immediate and specific feedback, and facilitate their self-assessment process. 
Although the results from Jing Jing's (2017) study indicated that students' perceptions of formative assessment practices are positive, they also reveal that students appreciate more when getting feedback from their teachers rather than from their classmates. It clearly shows that EFL teachers need to keep on using these assessment practices in English language classrooms and help students become more familiar with the feedback process. It can lead them to appreciate and rely more on their peers' suggestions. If students are frequently engaged in assessing each other, they can start seeing the validity of both, their teacher's assistance and their peers' support.

As Jing Jing (2017) mentions, students' lack of trustworthiness on formative assessment practices like peer assessment is due to their fixed perception of teachers' and students' roles in the teaching and assessment process. This shows that there is still a lot to be done in order to encourage students to change their negative perceptions towards peer assessment and feedback and move from a teacher-center to a student-center scaffolding. If more EFL teachers use formative assessments like peer assessments to encourage students to value their classmates' contributions, they might start taking more ownership for their learning in order to improve their English knowledge, as well as their language skills.

Improving Writing Language Skills. Assessing language productive skills like writing may be a challenging job, especially when working in EFL classrooms that have many students. Therefore, it is vital to present information about how formative assessments have been increasingly incorporating into several EFL classrooms around the world as a way to promote student learning and participation, as well as to decreased too much teacher intervention.

For instance, one study conducted by Naghdipour (2017) has analyzed the application of formative assessment in the Iranian EFL classroom and their impact on students' writing performance and their attitudes toward writing. The researcher analyzed thirty-four, first-year 
undergraduates and used pre- and post-study writing tasks, pre- and post-study questionnaires, and semi-structured interviews to collect information about their performance. The results of this study show that the application of formative assessment helped students improve their writing skills and develop positive attitudes toward writing.

In addition, the findings described that students value having formative assessment strategies, such as peer review, peer- and self- assessments, as well as portfolios since these tools let them identify specific strengths and weaknesses to enhance their writing tasks. As a result, this study reinforces the idea of implementing formative assessments to foster EFL student accountability for their learning, reduce teachers' workload by having students assess and support each other. What is more, it these kinds of assessments allow teachers to closely monitor students' improvement and keep a record of their writing progress.

Giving and Receiving Feedback. Despite the fact that formative assessments have been considered as important tools to identify strengths and weaknesses in order to provide immediate feedback on student learning, there may be some EFL teachers and students who do not value them. Thus, it is relevant to examine Burner's (2016) research work which examined the validity of formative assessments from the teachers' and learners' perspectives. This four-year longitudinal study was conducted in Norwegian EFL writing classes in order to gather information about teachers' and students' perceptions of formative assessments. After using teacher interviews, focus-group student interviews, and surveys, Bruner (2016) found out several contradictions between teachers' and students' perceptions of the formative assessment of writing. These contradictions were related to feedback, grades, text revision, self-assessment, and student involvement. 
For instance, Bruner's (2016) reported that when students were exposed to formative assessment practices, they did not really see their value since teachers just provided negative comments. Nevertheless, teachers affirmed that they have provided as much effective feedback as possible in English and Norwegian so that students can improve their writing skills. This clearly shows that even though formative assessments allowed teachers to provide feedback, it was not appropriate for students since teachers just concentrated on the negative aspects.

To avoid having these contradictory perspectives about receiving and providing feedback, it is essential to evaluate whether or not the provided comments are useful. As Black and William (1998) underline, the use of feedback needs to be considered as a tool to scaffold learning since it enables students to receive specific information about how to improve particular skills instead of just pointing out something that is incorrect.

Apart from these contradictions about the feedback generated by the application of formative assessments, Burner (2016) also reports some challenges. One of them showed that applying formative assessments to check students' writing progress was time-consuming for teachers since it requires to provide individual and detailed written feedback for each student. This study findings also revealed that student were frustrated after receiving feedback from their teachers since they had lack of school time to have one-on-one meetings to follow up and discuss on their teacher comments. Together, the contradictions and challenges based on teachers' experiences and students' perceptions about formative assessments point out that before advocating for their implementation, it is extremely necessary to make sure that teachers and students have a clear understanding of how to give and receive formative feedback to make some sounded contribution and progress. 
Monitoring Oral Performance. Assessing students' English oral production when using formative assessments has been described as an arduous task for EFL teachers (Ruiz-Primo, 2011). As such, it is relevant to analyze research studies to see how other EFL teachers have used them, as well as to examine students' reactions towards these assessment practices. To illustrate, Hirasawa (2013) analyzed five English teachers and twenty EFL Japanese students in a foreign language institute in Tokyo in order to see the effect of self- assessment on foreign language students' oral skills. The study lasted three months and let the researcher conducted pre- and post-tests, and videotaping interviews to gather important data about formative assessment applications and students' reactions.

For this study, Hirasawa (2013) used a self-assessment checklist with subcategories related to the organization of the presentation, content, linguistic factors, and interaction with the audience. The major findings indicated that using self-assessments have a positive influence on students' oral performance ability since they have the opportunity to reflect on their own learning growth. Although the results were positive, the researcher suggests analyzing and interpreting them carefully, since the study had a small number of participants.

This study shows that despite the fact that there were positive findings of formative assessments as tools to help EFL students develop independent strategies to recognize their strengths and weakness to improve their oral production, there is the need to conduct more research studies taking into account a larger population to validate the results.

Exploring General Language Proficiency Growth. Over the last years, it has been difficult to reach an agreement about the implementation of formative and summative assessments in EFL settings. Thus, exploring and presenting information about research studies on the impact of assessment methods on foreign language proficiency growth is essential. For 
instance, a longitudinal study conducted by Ross (2005) analyzed and compared language proficiency growth when using formative and summative assessments. The study lasted eight years and included 2215 Japanese EFL undergraduates that belonged to eight cohorts of foreign language learners. This study used a mixed-mode approach, parallel growth models, a group added growth model, and direct multivariate tests. The research results indicated that formative assessment practices, such as self- assessments, peer-assessments, portfolios, and group projects produce fundamental skill-specific effects on language proficiency growth. For instance, the findings show that these assessments helped improve students' listening comprehension, but there was not much academic reading growth. Hereafter, Ross (2005) suggests conducting future meticulous investigation to analyze the influences of this discrepancy of growth across English language skills.

This research study offers information about positive students' language proficiency growth, but it also shows possible limitations of certain formative assessment practices to help EFL students improve their four language skills: listening, speaking, reading, and writing. As such, it reinforces the need for evaluating the impacts of formative assessments on specific English language skills to analyze to what extent certain strategies may or may not help students improve their overall language proficiency.

\section{Unveiling Teacher Understanding of Formative Assessments}

Some researchers argue that it has been difficult to identify for certain whether or not teachers use formative assessment in their classrooms as tools to inform their teaching and support students to enhance their English knowledge and language skills. To analyze this issue in depth, researchers like Foster and Poppers (2009) as well as Kuzel and Shumba (2011) have examined teachers' formative assessment practices. These studies explained that most teachers 
did not know about formative assessments, and only a few had a general idea about them but were not able to properly design them. As such, students only got a score and did not receive any help to improve their learning achievement.

Observing Teacher Assessment Practices. It has been challenging to determine whether the use of formative assessments really improve learning or if they are simply used as grading tools. Therefore, Widiastuti and Saukah (2017) have conducted qualitative research to analyze teachers' understanding of formative assessments and how they influenced the follow-up actions in response to students' learning problems. The researchers included three junior high school teachers and three junior high school students in their study. The data for this study was collected through semi-structured interviews. The research findings revealed that English teachers had a low understanding of the nature of formative assessment and could not provide effective feedback to help students improve their learning. The results also showed that there was no implementation of proper follow-up actions to enhance the teaching and learning process. All in all, this research work explains the need of teachers to get more information about the role of formative assessments, the use of feedback, as well as the application of follow-up activities to scaffold students and benefit their learning.

Analyzing Teacher Assessment Preparation. In 2017, another study was conducted by Saito and Inoi in order to analyze the use of formative assessment by EFL teachers. The researchers included 727 participants who were Japanese junior and senior high school EFL teachers. This research work used William's (2010) model of formative assessment strategies to examine differences in the use of formative assessments in EFL teaching contexts. This study gathered information through a large-scale survey, interviews, observations, as well as follow-up questionnaires and emails. The results showed varying degrees of formative assessment use and 
classified teachers into three categories: high, middle, and low users taking into account four variables: intentions, methods, purposes, and feedback. Although Japanese teachers were classified in different users' categories, the study found that most of them were classified as middle and high users which shows teachers' readiness to apply formative assessments.

Subsequently, this study points out the relevance of providing a training program for teachers so that they can effectively apply formative assessments in EFL classrooms. It also emphasizes that once teachers start implementing formative assessments in their classrooms, it is important to have specific instruments to evaluate them, such as the theoretical framework proposed by William (2010).

All the aforementioned studies emphasize that there are multiple factors strongly influencing teachers' and students' implementation of formative assessments. Consequently, they need to be examined in depth in order to accomplish their overarching function of "evaluating students in the process of "forming" their competences and skills with the goal of helping them to continue that growth process" (Brown and Abeywickrama, 2018, p. 8).

\section{Conclusion}

\section{Encouraging and Challenging Findings}

The body of literature described above emphasizes the relevance of having a clear understanding of the purpose of formative assessment practices and describes several benefits and challenges of their implementations in EFL classrooms. To start, Gordon and Rajagopalan (2016), Gottlieb (2016), Heritage (2010), Moss and Brookhart (2009), and Popham (2008) have underlined that before implementing these assessments, teachers and students need to know why it is relevant to use them and how to use them. Otherwise, it is going to be difficult for teachers 
to provide effective feedback based on the assessment results, and for students to understand it in order to advance in their learning and achieve specific goals.

On one hand, studies from Leahy et al. (2005) and Jing Jing (2017) report that students actually value formative assessments since they help self-assess their learning as well as receive detailed feedback from their teachers. Nonetheless, the common concern of their research shows that students do not really appreciate receiving feedback from their peers.

On the other hand, Burner's (2016) study points out two specific findings. The first one is that students do not value receiving feedback from their teachers since it only underlines negative aspects. The second one shows that providing written feedback is challenging since it is time-consuming for teachers, and students also report not having plenty of class time to discuss and analyze that kind of extensive feedback with their teachers.

Additionally, when analyzing the influence of formative assessments to improve language skills, Naghdipour's (2017) work points out that peer reviews, peer- and selfassessments, and portfolios help students improve and develop positive attitudes towards writing. Hirasawa (2013) also explains that when formative assessments are properly applied, they allow students to identify their strengths and weaknesses related to their oral performance. However, Ross' (2005) study shows that these assessments need to be carefully applied and have an impact analysis on specific language skill improvements. For example, her research results report that formative assessments help students improve their listening comprehension, but they do not support their academic reading growth.

Furthermore, the research findings and analysis of Foster and Poppers (2009), Kuzel and Shumba (2011), as well as, Widiastuti and Saukah (2017) explain that when teachers do not have a clear understanding of formative assessment practices, it is difficult for them to design and 
provide useful follow-up activities to enhance EFL students' learning. Therefore, as Saito's and Inoi's (2017) highlights it is relevant to know about formative assessments' methods and purposes, as well as, how to provide feedback to the learners before implementing them in class. Their research study reveals that the majority of EFL teachers, who knew about formative assessments, were able to properly apply them in their classrooms.

\section{Future Research}

The inconsistency of the research results previously summarized emphasizes the need to conduct future research to examining not only teachers' knowledge of formative assessments but also their implementation and students' reactions toward them. Thus, some appealing questions of future research are: What are EFL teachers' understanding of formative assessments? What formative assessments do they use to evaluate the four language skills? What follow-up activities do they use after applying formative assessments? Similarly, these research questions can help gather information about the implementation: What facilitates the implementation of formative assessments? What is the relationship(s) among formative assessments, feedback and learning improvement? Finally, to analyze students' points of view, these could be some research questions: What are EFL students' perceptions of formative assessments? What aspects of formative assessment do they appreciate? What causes them to value teachers' feedback more than their peers'?

\section{Challenging Actions}

Although many researchers have shown that formative assessments not only help students, but teachers since they guide them to identify strengths and weaknesses and make informed decisions to improve instruction, there is still the need to advocate for their dissemination in EFL classrooms. Therefore, it seems that it is never too late to advocate for their 
use to achieve higher English language standards and improve the quality of English instruction in EFL settings. However, as Bronfenbrenner (2001) highlighted, a developmental processes emerge from people and context constant interactions, so it requires to consider characteristics from people, environment, and historical time. Therefore, it can be said that promoting the application of formative assessments in EFL settings may take time and require to start making crucial modifications at the macro, meso, and micro educational levels.

For instance, in non-native English-speaking countries, educational authorities need to start questioning the national assessment policies to find out possible strengths and weaknesses. It will lead to conduct a detailed revision process, make the necessary modifications of national language assessment guidelines, and approve formative assessments as new English assessment practices at the macro level. Then, school administrators need to create a plan to offer teacher training about the new formative assessment practices at the meso level. Finally, when talking about the micro-level, teachers must be willing to incorporate the new learnings acquired from their training program into their daily lessons and make sure students become familiar with them.

All in all, following this process to implement formative assessments in order to create meaningful opportunities for students to improve their English language, and not only domain isolated strategies to pass a test will take time. As it was previously described, it requires to have willingness to improve pre-established policies and traditional teaching and learning assessment practices in EFL classrooms. What is more, it requires having administrators, teachers, and students to work as a team to increase English proficiency levels and have better personal and professional opportunities. As Gallegos (2008) suggested, the English teaching and learning in Ecuador in particular needs to be seen as an educational reform capable of helping citizens to have equitable life opportunities. 


\section{References}

Black, P. J., \& Wiliam, D. (1998). Inside the black box: Raising standards through classroom assessment. Phi Delta Kappan, 80(2), 139-148.

Black, P., \& Wiliam, D. (1998). Assessment and classroom learning. Assessment in Education: Principles, Policy \& Practice, 5(1), 7-74.

Bloom, B. (1984). The search for methods of group instruction as effective as on-to-one tutoring. Educational Leadership, 41(8), 4-17.

Bloom, B. S. (1969). Some theoretical issues relating to educational evaluation. In R. W. Taylor (Ed.), Educational evaluation: New roles, new means: The $68^{\text {th }}$ yearbook of the National Society for the Study of Evaluation, Part II (pp. 26-50). Chicago: University of Chicago Press.

Bronfenbrenner, U. (2001). The bioecological theory of human development. In N. J. Smelser \& P. B. Baltes (Eds.), International encyclopedia of the social and behavioral sciences (pp. 6963- 6970). Oxford, UK: Elsevier.

Brown, H. D., Abeywickrama, P. (2018). Language Assessment: Principles and Classroom Practices. United Kingdom: Pearson Education.

Burner, T. (2016). Formative assessment of writing in English as a foreign language. Scandinavian Journal of Educational Research, 60(6), 626-648.

Cauley, M. K., \& McMillan, H. J. (2010). Formative assessment techniques to support student motivation and achievement. The Clearing House: A Journal of Educational Strategies, Issues and Ideas, 83 (1), 1-6.

Chappuis, S., \& Stiggins, R. J. (2002). Classroom assessment for learning. Educational leadership, 60(1), 40-44.

Council of Europe. (2011). Common European framework of reference for languages: Learning, teaching, assessment. Cambridge: Cambridge University Press.

Colley, K. (2008). Performance-based assessment. Science Teacher, 75(8), 68-72.

Foster. D., \& Poppers, A. 2009. Using Formative Assessment to Drive Learning. Silicon Valley: The Noyce Foundation. 
Gallegos, R. R., Martín, F., Oleas, J., Martínez, D., Minteguiaga, A., Campuzano, A., ... \& Ramírez, R. (2008). Igualmente pobres, desigualmente ricos. Programa de las Naciones Unidas para el Desarrollo.

Gordon, E. W., \& Rajagopalan, K. (2016). The Testing and Learning Revolution: The Future of Assessment in Education. New York, NY: Palgrave Macmillan.

Gottlieb, M. (2016). Assessing English language learners: Bridges to educational equity: Connecting academic language proficiency to student achievement. Corwin Press.

Hattie, J., \& Timperley, H. (2007). The power of feedback. Review of Educational Research, $77(1), 81-112$.

Heritage M. (2010). Formative assessment and next-generation assessment systems: Are we losing an opportunity? Council of Chief State School Officers.

Hirasawa, A. (2013). Self-Assessment and Oral Performance Ability: The Case of Japanese Learners. Online Submission.

Jing Jing, M. (2017). Using Formative Assessment to Facilitate Learner Self-Regulation: A Case Study of Assessment Practices and Student Perceptions in Hong Kong. Taiwan Journal of TESOL, 14(1), 87-118.

Kuzel, M.W., \& Shumba, A. 2011. An Investigation into Formative Assessment Practices of Teachers in Selected Schools in Fort Beaufort in South Africa. J Soc Sci Journal, 29 (2):159170.

Lee, I., \& Coniam, D. (2013). Introducing assessment for learning for EFL writing in an assessment of learning examination-driven system in Hong Kong. Journal of Second Language Writing, 22(1), 34-50.

Leahy, S., Lyon, C., Thompson, M., \& Wiliam, D. (2005). Classroom assessment: Minute by minute, day by day. Educational Leadership, 63(3), 18-24.

Ministry of Education. (2011). Acuerdo Ministerial No. 242-11. Quito, Ecuador: Government Printing Office

Moss, C. M., \& Brookhart, S. M. (2019). Advancing formative assessment in every classroom: A guide for instructional leaders. ASCD. 
Naghdipour, B. (2017). Incorporating formative assessment in Iranian EFL writing: A case study. The Curriculum Journal, 28(2), 283-299.

Pat-El, R. J., Tillema, H., \& Segers, M. (2013). Validation of assessment for learning questionnaires for teachers and students. British Journal of Educational Psychology, 83(1), 98-113.

Popham, W. J. (2009). Assessment literacy for teachers: Faddish or fundamental? Theory into Practice, 48(1), 4-11.

Richards, J. C. (2015). Key Issues in Language Teaching. Cambridge: Cambridge University Press.

Ross, S. J. (2005). The impact of assessment method on foreign language proficiency growth. Applied linguistics, 26(3), 317-342.

Ruiz-Primo, M. A. (2011). Informal formative assessment: The role of instructional dialogues in assessing students' learning. Studies in Educational Evaluation, 37(1), 15-24.

Saito, H., \& Inoi, S. I. (2017). Junior and senior high school EFL teachers' use of formative assessment: A mixed-methods study. Language Assessment Quarterly, 14(3), 213-233.

Serrano, M. E., Vizcaíno, C. G., Cazco, D., \& Kuhlman, N. A. (2015). Transformation: A model for restructuring the preparation of English teachers in Ecuador. GIST-Education and Learning Research Journal, (11), 103-117.

Viktorovna, K. M., \& Arkadyevna, S. L. 2015. Formative Assessment as a Component of the Future English Teacher Training. International Education Studies, 8 (8): 157-165.

Widiastuti, I. A. M. S., \& Saukah, A. (2017). Formative assessment in efl classroom practices. Bahasa dan Seni: Jurnal Bahasa, Sastra, Seni, dan Pengajarannya, 45(1), 50-63.

Wiliam, D. (2010). An integrative summary of the research literature and implications for a new theory of formative assessment. In H. L. Andrade, \& G. J. Cizek (Eds.), Handbook of formative assessment (pp. 18-40). New York, NY: Routledge. 